\title{
Influence of Mineral Salts on Shoot Growth and Metabolite Biosynthesis in Tea Tree (Camellia sinensis L.)
}

\author{
Yong Duck Kim ${ }^{1}$, Jae Gill Yun ${ }^{2}$, Yeong Rong Seo ${ }^{3,4}$, Chandrakant S. Karigar ${ }^{5}$, and Myung Suk Choi ${ }^{3,4^{*}}$ \\ ${ }^{1}$ Institute of Hadong Green Tea, Hadong 667-804, Korea \\ ${ }^{2}$ Department of Horticulture, Gyeongnam National University of Science and Technology, Jinju 660-701, Korea \\ ${ }^{3}$ Division of Environmental Forest Secience, Gyeongsang National University, Jinju 660-768, Korea \\ ${ }^{4}$ Institute of Agriculture and Life Science, Gyeongsang National University, Jinju 660-768, Korea \\ ${ }^{5}$ Department of Biochemistry, Tumkur University, Tumkur, 572103, India
}

\begin{abstract}
Effects of mineral salts $\left(\mathrm{N}, \mathrm{P}, \mathrm{K}, \mathrm{Ca}^{2+}, \mathrm{Mg}^{2+}\right.$, and $\left.\mathrm{Fe}^{3+}\right)$ on the shoot growth and metabolite production of tea tree were studied using in vitro culture techniques. Among mineral salts, $\mathrm{H}_{2} \mathrm{PO}_{4}{ }^{-}$was the most important for enhanced growth rate of tea tree, while $\mathrm{Mg}^{2+}$ and $\mathrm{Ca}^{2+}$ did not affect plant growth. Removal of $\mathrm{NH}_{4}{ }^{+}$and $\mathrm{NO}_{3}$ from the culture medium enhanced shoot multiplication compared to other treatments. Metabolite production was variable depending on mineral types and concentration. Removal of $\mathrm{Ca}^{2+}$ decreased the production of caffeine; however, other treatments did not influence its production. $\mathrm{Ca}^{2+}, \mathrm{NH}_{4}^{+}$ and $\mathrm{Fe}^{3+}$ were important factors for catechin production in tea tree. These results can be used as the basis for development of technical soil controls suitable for tea tree cultivation in the future.
\end{abstract}

Additional key words: amino acids, caffeine, catechins

\section{Introduction}

Tea tree (Camellia sinensis L.) belongs to the family Theaceae. Tea extract is the oldest non- alcoholic beverage being consumed throughout the world. Chinese were among the first to use tea leaf extract as medicinal drink, later as beverage since 3,000 years (Eden, 1958). Tea tree is one of the most important plantation crops in the world. Tea leaves have more than 700 diverse chemical constituents including flavonoids, amino acids, vitamins (C, E, and $\mathrm{K}$ ), caffeine, catechins and polysaccharides which are significant to human health.

Growth of plant and production of secondary metabolites are important aspects in tea tree cultivation. Nutrients affect plant growth and survival (Albert and Kinzel, 1973; Chae et al., 2006). Among nutrients, 17 of them influence tea plant growth and secondary metabolites production. Especially, the presence and variations in the amount of inorganic salts in the form of macro-elements and microelements are known to affect the productivity of plants and the content of useful substances (Orians et al., 2003; Park, 1995). Elevating the concentration of mineral salts considerably stimulated growth of the shoots, whereas the content of the sterol glycosides in their leaves decreased by about order of magnitude (Bondarev et al., 2003). The research so far has been conducted on determining the effect of total composition on plant growth and metabolite biosynthesis, however results directed towards establishing the contribution of each mineral salt on plant growth and metabolites biosynthesis have not been reported.

In vitro plant cultivation approach provides an advantage of controlling the environmental factors with ease. The information obtained with in vitro examination, one can grasp the conditions suitable for the in vivo cultivation of the plant. Therefore the so called "in vitro monitoring" of tea tree can aid in determination of conditions for

\footnotetext{
*Comesponding author: mschoi@gnu.ac.kr

※ Received 2 April 2014; Revised 10 October 2014; Accepted 23 October 2014. This research was supported by Ministry of Agriculture, Food and Rural Affairs and the Korea Science, the Rural Development Administration (PJ008336).

(C) 2015 Korean Society for Horticultural Science
} 
optimal field cultivations. Nutrient media for plant tissue culture are designed to allow plant tissues to be maintained in a totally artificial environment. In vitro culture allows monitoring of the plant responses under varied biochemical and physiological conditions (Shibli et al., 2000). Examining the effects of plant growth and metabolites generation has not been carried out for tea under in vitro conditions. The purpose of this study was to assess the influence of different mineral salts on shoot growth and secondary metabolites production in cultured tea trees.

\section{Materials and Methods}

\section{Plant Material and in Vitro Cultures}

Three year old in vitro cultured tea trees (Camellia sinensis L.) from Institute of Hadong Green Tea, Hadong, South Korea were selected. Explant was a homogeneous clone selected from tea plants. The explants were cultured in Petri dishes $(9 \mathrm{~cm})$ containing $20 \mathrm{~mL}$ of $1 / 2 \mathrm{MS}$ (Murashige and Skoog 1962) supplemented with 1.44 mol of BAP (Duchefa, Haarlem, The Netherlands), sucrose (3\% w/v), and gelite $(0.38 \% \mathrm{w} / \mathrm{v})$ (Duchefa, Haarlem, The Netherlands). Plantlets were then subcultured on $1 / 2$ MS medium without plant growth regulators. All plates were incubated in a growth chamber fitted with a cool fluorescent light emitting 25 $\mu \mathrm{mol} \cdot \mathrm{m}^{-2} \cdot \mathrm{s}^{-1}$ of photosynthetically active radiation (PAR) at $25 \pm 1^{\circ} \mathrm{C}$ during 12 weeks. Each experiment involved a total of 5 plates per treatment and as triplicates.

\section{Rationing of Mineral Salts}

Individual shoots were cut from the multiple shoot clusters and allowed to proliferate on the basal $1 / 2 \mathrm{~S}$ solid medium without any plant growth regulators for 12 weeks. The effects of mineral salts on shoot growth and metabolites biosynthesis was determined by culture of the plantlets on 1/2 MS medium without each mineral salt. The medium for the in vitro culture consisted of macronutrients as in $1 / 2 \mathrm{MS}\left(\mathrm{NH}_{4} \mathrm{NO}_{3}, 2.0625 \mathrm{~g} \cdot \mathrm{L}^{-1} ; \mathrm{KNO}_{3}, 2.375 \mathrm{~g} \cdot \mathrm{L}^{-1} ; \mathrm{KH}_{2} \mathrm{PO}_{4}\right.$, $0.2125 \mathrm{~g} \cdot \mathrm{L}^{-1} ; \mathrm{MgSO}_{4} 7 \mathrm{H}_{2} \mathrm{O}, 9.25 \mathrm{~g} \cdot \mathrm{L}^{-1} ; \mathrm{CaCl}_{2} 2 \mathrm{H}_{2} \mathrm{O}, 5.5 \mathrm{~g} \cdot \mathrm{L}^{-1}$; $\mathrm{KI}, 0.0415 \mathrm{~g} \cdot \mathrm{L}^{-1}$ and $\mathrm{FeSO}_{4} 7 \mathrm{H}_{2} \mathrm{O}, 0.139 \mathrm{~g} \cdot \mathrm{L}^{-1}$ ). The experimental media were prepared as follows: M1, control (1/2 MS); M2, without $\mathrm{NH}_{4}{ }^{+}$; $\mathrm{M} 3$, without $\mathrm{NO}_{3} ; \mathrm{M} 4$, without $\mathrm{H}_{2} \mathrm{PO}_{4}{ }^{-}$; M5, without $\mathrm{K}^{+}$; $\mathrm{M} 6$, without $\mathrm{Ca}^{2+}$; $\mathrm{M} 7$, without $\mathrm{Mg}^{2+}$; and $\mathrm{M} 8$, without $\mathrm{Fe}^{3+}$. Each of the resulting media was supplemented with full-strength vitamins, sucrose $\left(30 \mathrm{~g} \cdot \mathrm{L}^{-1}\right)$, and gelrite $\left(4.0 \mathrm{~g} \cdot \mathrm{L}^{-1}\right)$. The $\mathrm{pH}$ of the medium was adjusted to 5.5 with $1 \mathrm{~N} \mathrm{NaOH}$ before autoclaving at $121^{\circ} \mathrm{C}$ for $15 \mathrm{~min}$. All cultures were maintained under a $16 \mathrm{~h}$ light $/ 8 \mathrm{~h}$ dark photoperiod, in a growth chamber fitted with a cool fluorescent light emitting $25 \mu \mathrm{mol} \cdot \mathrm{m}^{-2} \cdot \mathrm{s}^{-1}$ of photosynthetically active radiation (PAR).

\section{Measurement of Shoot Growth and Plant Appearance}

The shoot growth of cultured plant was measured after 4 weeks of culture. The growth rate tea shoot was represented as growth index (GI) as calculated using the following equation;

$$
\begin{aligned}
\mathrm{GI}= & \text { (Final shoot length }- \text { Inoculated shoot length) } / \\
& \text { Inoculated shoot length }
\end{aligned}
$$

The leaf browning and necrosis were measured visually for 12 weeks with two weeks make observations of the tea tree. The appearance of plant, browning and necrosis of leaves were scored visually after 12 weeks of growth. The measurements were undertaken for three times.

\section{Quantification of Caffeine and Catechins}

The quantitative analysis of catechins was validated by HPLC analysis. The samples of tea extracts were subjected to HPLC as described previously (Kim et al., 2010). Quantitative analysis of catechins was achieved by co-chromatogram of the standards and samples and by comparison of the retention times. The samples for HPLC were selected on the basis of the primary screening of tea trees through colorimetric method. Quantification was repeated for a minimum of three times.

\section{Quantitative Analysis of Amino Acids from Tea Extracts}

To estimate free amino acids found in tea extracts, the leaves (FW, $100 \mathrm{mg}$ ) were homogenized and extracted with $10 \mathrm{~mL}$ of trichroloacetic on a hot water bath (ANALAB KSB-201) at $30^{\circ} \mathrm{C}$ for $2 \mathrm{~h}$. Extracts were clarified by centrifugation at 4,500 rpm for $15 \mathrm{~min}$ and filtered through $0.45 \mu \mathrm{m} \mathrm{CA}$ membrane (MFS-25, Advantec, MFS, Inc., CA, USA). Amino acid analysis of samples was conducted as described previously (Kato et al., 2003). The results were expressed as in Millenium 32 program.

\section{Statistical Analysis}

The experiments were conducted for a minimum of three to five times with repetitive results. Duncan's multiple range test (DMRT) was used to analyze the variations. Values were represented as mean \pm standard deviation (SD).

\section{Results}

Effect of Mineral Salts on Shoot Growth and Rooting of Tea Tree

Mineral salts had dramatic effects on tea plant growth 
(Fig. 1). The growth rate was high when plant was cultured on M7 $\left(\mathrm{Mg}^{2+}, 0.38 \pm 0.17 \mathrm{~cm}\right)$ less medium while the plantlets cultured on $\mathrm{M} 4\left(\mathrm{H}_{2} \mathrm{PO}_{4}{ }^{-}, 0.07 \pm 0.08 \mathrm{~cm}\right)$ free medium showed poor shoot growth. This observation indicated that $\mathrm{H}_{2} \mathrm{PO}_{4}^{-}$has a positive effect on tea cultures while $\mathrm{Mg}^{2+}$ does not influence the same. Growth pattern of tea plant was similar in response to every treatment over 12 weeks.

Root induction from tea plantlets was dependent on type of mineral salts (Fig. 2). Removal of $\mathrm{M} 7\left(\mathrm{Mg}^{2+}, 100 \%\right)$ from medium is beneficial for root formation in tea tree plants. However, $\mathrm{M} 2\left(\mathrm{NH}_{4}{ }^{+}, 20 \%\right)$ and $\mathrm{M} 3\left(\mathrm{NO}_{3}{ }^{-}, 20 \%\right)$ less media had varying influence on rooting. In addition, removal of $\mathrm{M} 4\left(\mathrm{H}_{2} \mathrm{PO}_{4}^{-}, 40 \%\right)$, M5 $\left(\mathrm{K}^{+}, 60 \%\right)$, M6 $\left(\mathrm{Ca}^{2+}, 60 \%\right)$

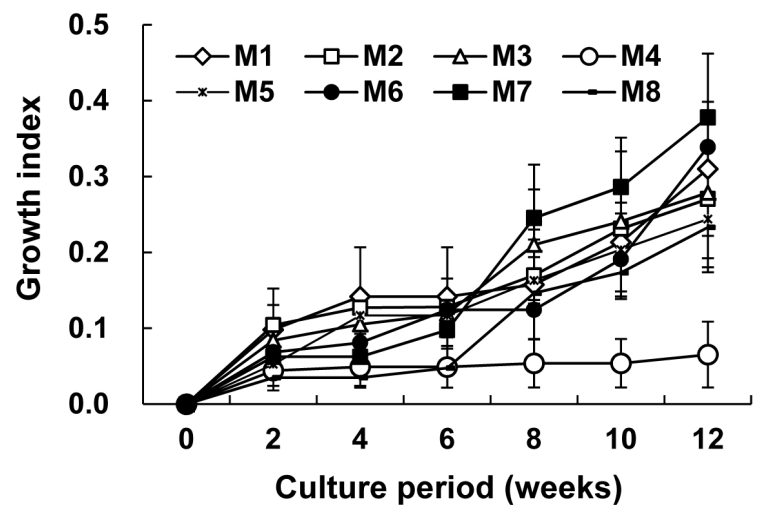

Fig. 1. Effects of various mineral salts on shoot growth from tea plant using 1/2 MS medium after 12 weeks of in vitro cultivation. M1, control (1/2 MS); M2, without $\mathrm{NH}_{4}{ }^{+}$; M3, without $\mathrm{NO}_{3}^{-}$; $\mathrm{M} 4$, without $\mathrm{H}_{2} \mathrm{PO}_{4}^{-}$; $\mathrm{M} 5$, without $\mathrm{K}^{+}$; $\mathrm{M} 6$, without $\mathrm{Ca}^{2+} ; \mathrm{M} 7$, without $\mathrm{Mg}^{2+}$; and $\mathrm{M} 8$, without $\mathrm{Fe}^{3+}$. and $\mathrm{M} 8\left(\mathrm{Fe}^{3+}, 60 \%\right)$ from culture media also enhanced rooting of tea trees.

The root formation was highly dependent on the presence of particular minerals (Fig. 2). $\mathrm{K}^{+}, \mathrm{Ca}^{2+}$, and $\mathrm{Fe}^{3+}$ removed media showed enhanced rooting to the extent of $60 \%$. However, the removal of $\mathrm{NH}_{4}{ }^{+}$and $\mathrm{NO}_{3}{ }^{-}$from medium lead to decreased rooting.

Tea Plant and Leaf Morphology after Growth in Culture Media with Different Mineral Salts

The number of leaves were less on tea plants cultured in medium without $\mathrm{H}_{2} \mathrm{PO}_{4}$. The leaves in tea plant were about 4.8 and 0.6 respectively after their culture in $\mathrm{K}^{+}$ and $\mathrm{H}_{2} \mathrm{PO}_{4}^{-}$free media (Table 1). Leaf morphology also varied depending upon each mineral treatment. Generally

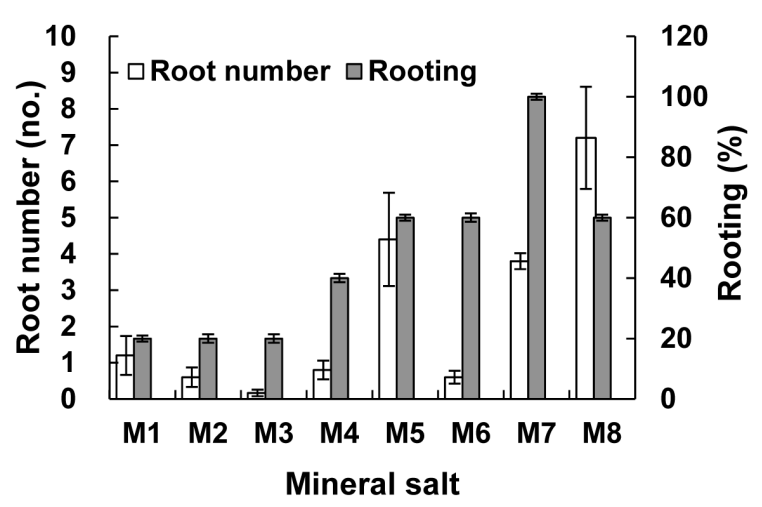

Fig. 2. Effect of mineral salts on rooting of tea tree after 12 weeks of cultures. M1, control $(1 / 2 \mathrm{MS})$; $\mathrm{M} 2$, without $\mathrm{NH}_{4}{ }^{+}$; M3, without $\mathrm{NO}_{3} ; \mathrm{M} 4$, without $\mathrm{H}_{2} \mathrm{PO}_{4}^{-}$; $\mathrm{M} 5$, without $\mathrm{K}^{+}$; M6, without $\mathrm{Ca}^{2+} ; \mathrm{M} 7$, without $\mathrm{Mg}^{2+}$; and $\mathrm{M} 8$, without $\mathrm{Fe}^{3+}$. Error bars show \pm SD.

Table 1. Effects of minerals on tea leaf growth and appearance following in vitro culture ${ }^{\mathrm{z}}$.

\begin{tabular}{llcr}
\hline Tested culture media $^{\mathrm{y}}$ & No. of leaves $^{\mathrm{x}}$ & Leaf browning (\%) & Leaf necrosis (\%) \\
\hline M1 & $4.0 \pm 0.04 \mathrm{a}$ & $12.5 \pm 0.10 \mathrm{~b}$ & $0 \pm 0.00 \mathrm{~b}$ \\
M2 & $2.0 \pm 0.08 \mathrm{ab}$ & $13.5 \pm 0.13 \mathrm{~b}$ & $20 \pm 0.45 \mathrm{~b}$ \\
M3 & $3.4 \pm 0.02 \mathrm{ab}$ & $13.6 \pm 0.14 \mathrm{ab}$ & $20 \pm 0.45 \mathrm{~b}$ \\
M4 & $0.6 \pm 0.06 \mathrm{~b}$ & $17.1 \pm 0.20 \mathrm{ab}$ & $80 \pm 0.45 \mathrm{a}$ \\
M5 & $4.8 \pm 0.06 \mathrm{a}$ & $22.8 \pm 0.16 \mathrm{ab}$ & $0 \pm 0.00 \mathrm{~b}$ \\
M6 & $4.0 \pm 0.06 \mathrm{a}$ & $26.2 \pm 0.14 \mathrm{a}$ & $80 \pm 0.45 \mathrm{a}$ \\
M7 & $3.6 \pm 0.03 \mathrm{ab}$ & $22.8 \pm 0.13 \mathrm{ab}$ & $0 \pm 0.00 \mathrm{~b}$ \\
M8 & $3.6 \pm 0.03 \mathrm{ab}$ & $26.0 \pm 0.05 \mathrm{a}$ & $0 \pm 0.00 \mathrm{~b}$
\end{tabular}

${ }^{z}$ Means with different superscripts in the same row are significantly different at $p<0.05$.

${ }^{\mathrm{y}} \mathrm{M} 1$, control $(1 / 2 \mathrm{MS})$; $\mathrm{M} 2$, without $\mathrm{NH}_{4}{ }^{+}$; $\mathrm{M} 3$, without $\mathrm{NO}_{3}^{-}$; M4, without $\mathrm{H}_{2} \mathrm{PO}_{4}{ }^{-}$; $\mathrm{M} 5$, without $\mathrm{K}^{+}$; M6, without Ca ${ }^{2+}$; M7, without $\mathrm{Mg}^{2+}$; and $\mathrm{M} 8$, without $\mathrm{Fe}^{3+}$.

${ }^{\mathrm{x}}$ Each value represents the mean \pm standard deviation of at least three replicates. 
browning of leaf was observed with passage of time and mineral salts removed treatments much affected. Leaves of plants cultured in $\mathrm{Ca}^{2+}$ and $\mathrm{Fe}^{3+}$ free media exhibited high browning. Also, leaf necrosis was high in $\mathrm{H}_{2} \mathrm{PO}_{4}{ }^{-}$and $\mathrm{Ca}^{2+}$ free media (Figs. 3D and 3F). However leaf browning in control plant was minimal.

\section{Effect of Mineral Salts on Multiple Shoot Induction}

The mineral salt composition of culture medium determined multiple shoot formation (Table 2). Multiple shoot formation was high in $\mathrm{H}_{2} \mathrm{PO}_{4}, \mathrm{NH}_{4}{ }^{+}$and $\mathrm{NO}_{3}{ }^{-}$less media. $\mathrm{NH}_{4}{ }^{+}$removal treatment resulted in about 2.4 multiple shoots. However,

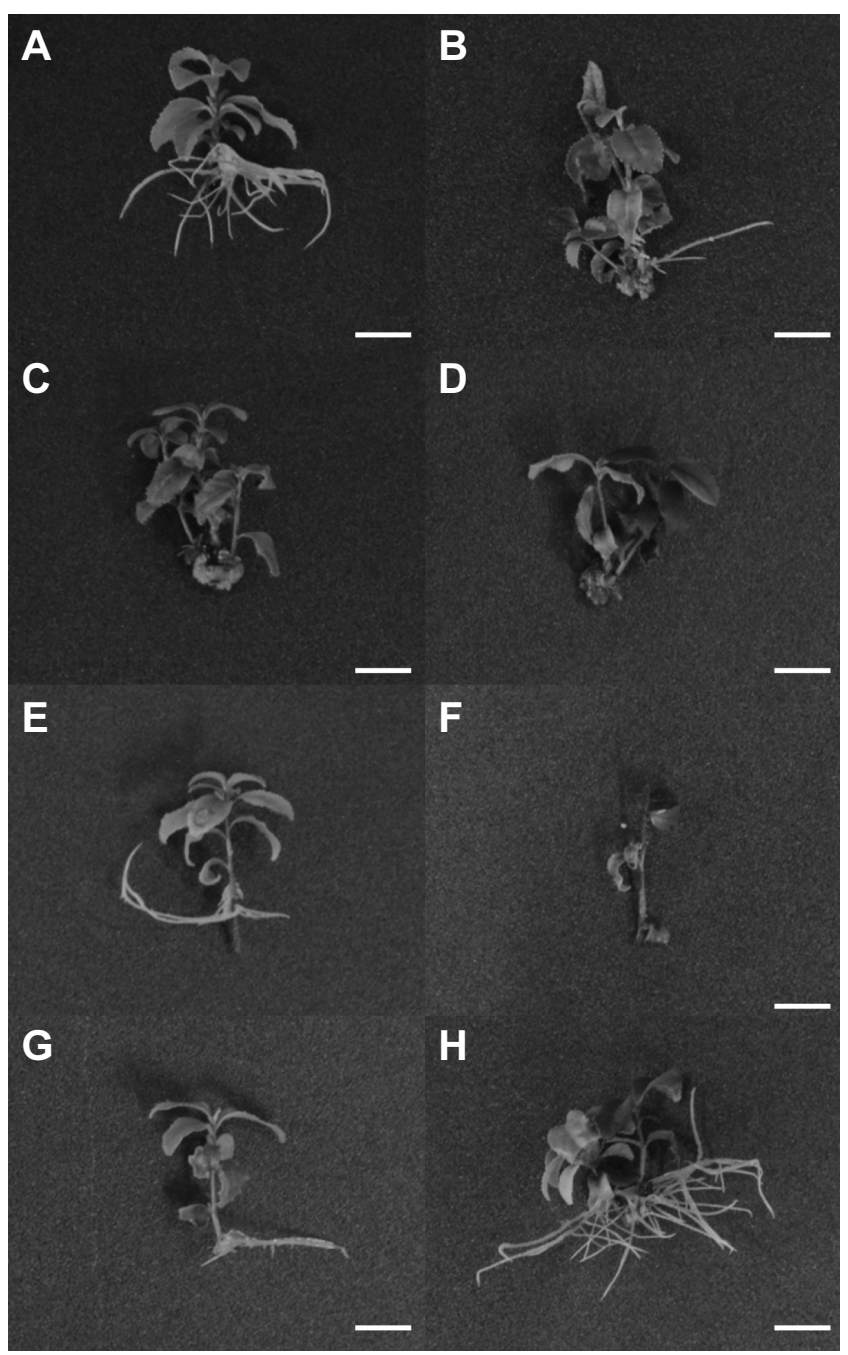

Fig. 3. Culture response of tea tree cultivated of $1 / 2 \mathrm{MS}$ medium containing different mineral salts after 12 weeks of in vitro cultivation. (A) M1, control (1/2 MS); (B) M2, without $\mathrm{NH}_{4}^{+}$; (C) $\mathrm{M} 3$, without $\mathrm{NO}_{3}^{-}$; (D) M4, without $\mathrm{H}_{2} \mathrm{PO}_{4}{ }^{-}$; (E) M5, without $\mathrm{K}^{+}$; (F) M6, without $\mathrm{Ca}^{2+}$; (G) M7, without $\mathrm{Mg}^{2+}$; and $(\mathrm{H}) \mathrm{M} 8$, without $\mathrm{Fe}^{3+}$. Scale bar $=10 \mathrm{~mm}$. multiple shoots were not induced in $\mathrm{Mg}^{2+}$ and $\mathrm{Fe}^{3+}$ removed culture medium.

\section{Variations in Tea Extract Caffeine and Catechins Due to Minerals in Media}

The changes in caffeine and catechins were analyzed after 12 weeks of cultivation. There appeared many changes in the metabolites like caffeine and catechins (EC, EGCG, EGC, and ECG) depending on the presence or absence of minerals in media. There was a large difference in metabolites depending upon the existence of specific minerals.

The concentration of caffeine was less in tea plants cultured in all other media except in medium deprived of $\mathrm{K}^{+}$(Fig. 4). Especially, caffeine production was low in plants cultured on the $\mathrm{NH}_{4}{ }^{+}\left(43.08 \mathrm{mg} \cdot \mathrm{g}^{-1} \mathrm{DW}\right)$ and $\mathrm{Ca}^{2+}$ (33.23 $\mathrm{mg} \cdot \mathrm{g}^{-1} \mathrm{DW}$ ) less medium was lower by about 2.1 times than that of other treatments.

Mineral salts also affected the catechins production by in vitro cultured tea trees. Catechins production in $\mathrm{Ca}^{2+}$ and $\mathrm{NH}_{4}{ }^{+}$deprived medium was lower than those of other medium conditions. However, $\mathrm{Fe}^{3+}$ absence in medium lead to enhanced catechin production.

All other medium conditions except $\mathrm{NH}_{4}{ }^{+}\left(30.28 \mathrm{mg} \cdot \mathrm{g}^{-1}\right.$ DW) and $\mathrm{Fe}^{3+}\left(27.69 \mathrm{mg} \cdot \mathrm{g}^{-1} \mathrm{DW}\right)$ absent treatments showed less EC content than the control $\left(24.86 \mathrm{mg} \cdot \mathrm{g}^{-1} \mathrm{DW}\right)$. Especially, $\mathrm{Ca}^{2+}\left(11.36 \mathrm{mg} \cdot \mathrm{g}^{-1} \mathrm{DW}\right)$ removal from medium resulted in about 2.9 times reduced EC. Every other medium condition

Table 2. Effects of mineral salts on multiple shoot formation of tea tree using 1/2 MS medium after 12 weeks cultivation ${ }^{\mathrm{z}}$.

\begin{tabular}{lcc}
\hline $\begin{array}{l}\text { Tested culture } \\
\text { media }_{\mathrm{y}}\end{array}$ & $\begin{array}{c}\text { Multiple shoot } \\
\text { frequency }(\%)^{\mathrm{x}}\end{array}$ & $\begin{array}{c}\text { No. of multiple } \\
\text { shoots }\end{array}$ \\
\hline M1 & $20 \pm 1.34 \mathrm{bc}$ & $0.6 \pm 0.27 \mathrm{bc}$ \\
M2 & $80 \pm 1.52 \mathrm{a}$ & $2.4 \pm 0.30 \mathrm{a}$ \\
M3 & $100 \pm 0.44 \mathrm{a}$ & $2.2 \pm 0.09 \mathrm{a}$ \\
M4 & $60 \pm 1.79 \mathrm{ab}$ & $1.8 \pm 0.36 \mathrm{ab}$ \\
M5 & $20 \pm 0.89 \mathrm{bc}$ & $0.4 \pm 0.18 \mathrm{bc}$ \\
M6 & $20 \pm 0.89 \mathrm{bc}$ & $0.4 \pm 0.18 \mathrm{bc}$ \\
M7 & $0 \pm 0.00 \mathrm{c}$ & $0.0 \pm 0.00 \mathrm{c}$ \\
M8 & $0 \pm 0.00 \mathrm{c}$ & $0.0 \pm 0.00 \mathrm{c}$ \\
\hline
\end{tabular}

${ }^{\mathrm{z}}$ Means with different superscripts in the same row are significantly different at $p<0.05$.

${ }^{\mathrm{y}} \mathrm{M} 1$, control (1/2 MS); M2, without $\mathrm{NH}_{4}{ }^{+}$; $\mathrm{M} 3$, without $\mathrm{NO}_{3}{ }^{-}$; M4, without $\mathrm{H}_{2} \mathrm{PO}_{4}^{-}$; $\mathrm{M} 5$, without $\mathrm{K}^{+}$; $\mathrm{M} 6$, without $\mathrm{Ca}^{2+} ; \mathrm{M} 7$, without $\mathrm{Mg}^{2+}$; and $\mathrm{M} 8$, without $\mathrm{Fe}^{3+}$.

${ }^{\mathrm{x}}$ Each value represents the mean \pm standard deviation of at least three replicates. 
except $\mathrm{NH}_{4}^{+}\left(5.37 \mathrm{mg} \cdot \mathrm{g}^{-1}\right.$ DW) devoid medium showed higher ECG. Among various mineral omissions, ECG content was high $10.78 \mathrm{mg} \cdot \mathrm{g}^{-1} \mathrm{DW}$ in $\mathrm{Fe}^{3+}$ less medium. EGCG and ECG levels were similar. $\mathrm{Fe}^{3+}$ deprivation resulted in 1.86

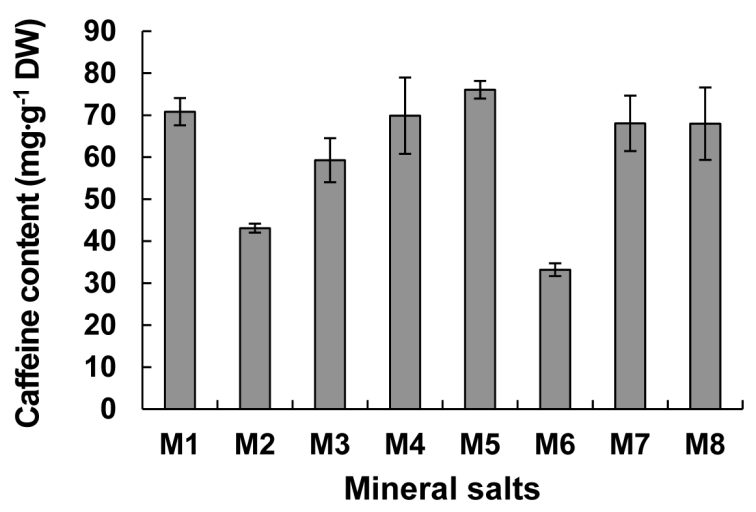

Fig. 4. Effect of mineral salts on caffeine content of tea leaves. M1, control (1/2 MS); M2, without $\mathrm{NH}_{4}{ }^{+}$; $\mathrm{M} 3$, without $\mathrm{NO}_{3}{ }^{-}$; $\mathrm{M} 4$, without $\mathrm{H}_{2} \mathrm{PO}_{4}^{-}$; $\mathrm{M} 5$, without $\mathrm{K}^{+}$; $\mathrm{M} 6$, without $\mathrm{Ca}^{2+}$; $\mathrm{M} 7$, without $\mathrm{Mg}^{2+}$; and M8, without $\mathrm{Fe}^{3+}$. Error bars show \pm SD. $\mathrm{mg} \cdot \mathrm{g}^{-1} \mathrm{DW}$. The EGC concentration of tea leaves was found to be $36.98 \mathrm{mg} \cdot \mathrm{g}^{-1} \mathrm{DW}$ after growth in $\mathrm{Ca}^{2+}$ less and on $\mathrm{NH}_{4}{ }^{+}$removed medium they were lower than those of other treatments (Fig. 5).

\section{Variation of Tea Extract - Amino Acids Due to Different Minerals}

The changes in amino acids of tea extracts were analyzed after 12 weeks of culture (Table 3). A total of 22 amino acids could be detected. On the contrary to the result shown for amino acids analysis, the $\mathrm{Ca}^{2+}$ removed treatment (M6, $27.76 \mu \mathrm{g} \cdot \mathrm{g}^{-1}$ ) showed 1.53 times higher total amino acid content than the control (M1, $\left.18.2 \mu \mathrm{g} \cdot \mathrm{g}^{-1}\right)$. However, $\mathrm{Fe}^{3+}$ removed treatment $\left(\mathrm{M} 8,7.6 \mu \mathrm{g} \cdot \mathrm{g}^{-1}\right)$ showed a 3.65 times lower content than the $\mathrm{Ca}^{2+}$ treatment. Level of amino acid was variable based on treatments. Among the amino acids arginine was highest.

\section{Discussion}

Mineral salts composition of culture media results in
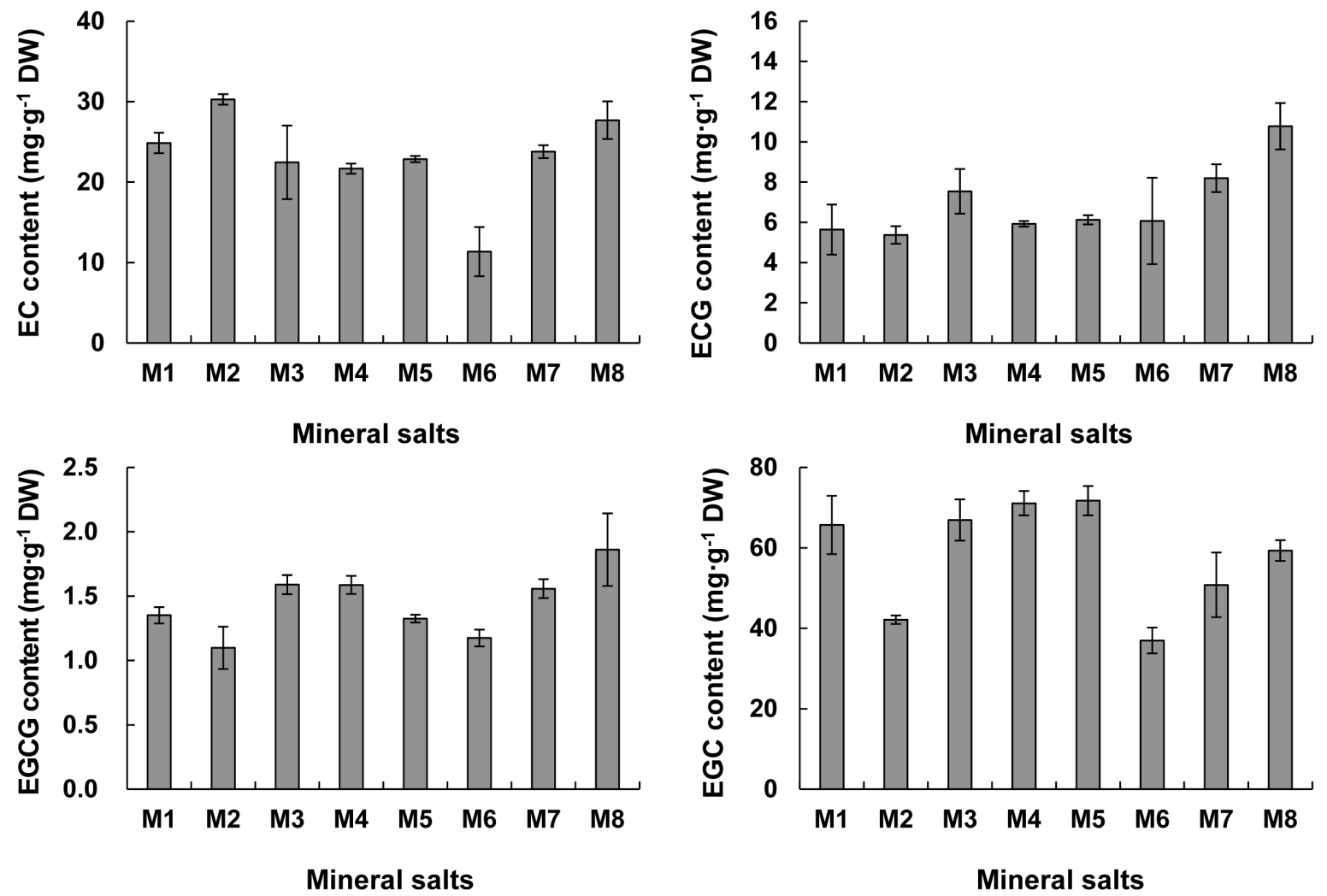

Fig. 5. Effect of mineral salts on catechins content in tea tree leaves. $\mathrm{M} 1$, control $(1 / 2 \mathrm{MS})$; $\mathrm{M} 2$, without $\mathrm{NH}_{4}{ }^{+}$; $\mathrm{M}_{3}$, without $\mathrm{NO}_{3}^{-} ; \mathrm{M} 4$, without $\mathrm{H}_{2} \mathrm{PO}_{4}^{-}$; M5, without $\mathrm{K}^{+}$; M6, without $\mathrm{Ca}^{2+}$; $\mathrm{M} 7$, without $\mathrm{Mg}^{2+}$; and M8, without Fe ${ }^{3+}$. Error bars show \pm SD. EC, (-)-epicatechin; ECG, (-)-epicatechin gallate; EGCG, (-)-epigallocatechin gallate; EGC, (-)-epigallocatechin. 
Table 3. Amino acid composition of tea extracts obtained from various mineral salts treatments.

\begin{tabular}{|c|c|c|c|c|c|c|c|c|}
\hline \multirow{2}{*}{ Amino acids } & \multicolumn{8}{|c|}{ Contents $\left(\mu \mathrm{g} \cdot \mathrm{g}^{-1}\right)$} \\
\hline & $\mathrm{M} 1^{\mathrm{z}}$ & M2 & M3 & M4 & M5 & M6 & M7 & M8 \\
\hline Phosphoserine & 0.2 & 0.1 & 0.1 & 0.1 & 0.1 & 0.2 & 0.1 & 0.1 \\
\hline Urea & 0.9 & 1.6 & 2.4 & 0.6 & 1.2 & 0.5 & 1.0 & 1.4 \\
\hline Aspartic Acid & 1.8 & 0.9 & 0.8 & 1.1 & 0.9 & 2.9 & 1.3 & 0.7 \\
\hline Threonine & 0.3 & 0.2 & 0.1 & 0.2 & 0.2 & 0.5 & 0.2 & 0.1 \\
\hline Serine & 0.9 & 0.7 & 0.7 & 1.1 & 0.7 & 3.1 & 1.4 & 0.5 \\
\hline Asparagine & 0.4 & 0.4 & 0.1 & 0.5 & 0.2 & 3.3 & 1.0 & 0.1 \\
\hline Glutamic Acid & 1.6 & 0.8 & 0.8 & 0.8 & 1.3 & 3.1 & 0.9 & 0.9 \\
\hline Theanine & 2.1 & 0.8 & 0.4 & 5.8 & 5.6 & 1.29 & 1.0 & 0.4 \\
\hline Glycine & 0.1 & 0.1 & $\mathrm{~s}^{\mathrm{y}}$ & - & - & 0.3 & - & - \\
\hline Alanine & 1.0 & 0.5 & 0.7 & 0.7 & 0.6 & 1.6 & 0.7 & 0.4 \\
\hline Valine & 0.2 & - & 0.1 & 0.3 & 0.2 & 0.8 & 0.1 & 0.1 \\
\hline Isoleucine & - & - & - & - & - & 0.1 & 0.1 & - \\
\hline Leucine & 0.1 & 0.1 & 0.1 & 0.1 & 0.1 & 0.2 & 0.1 & - \\
\hline Tyrosine & 0.1 & - & 0.1 & 0.1 & 0.1 & - & 0.1 & - \\
\hline B-Amino isobut & - & - & - & - & - & 0.1 & - & \\
\hline GABA & 0.5 & 0.3 & 0.6 & 0.7 & 0.4 & 1.5 & 0.6 & 0.3 \\
\hline Histidine & 0.1 & 0.1 & - & 0.1 & 0.1 & 0.4 & 0.1 & - \\
\hline Carnosine & 0.1 & - & 0.1 & 0.1 & 0.1 & 0.1 & 0.1 & 0.1 \\
\hline Ornithine & 0.1 & 0.1 & 0.1 & 0.1 & 0.1 & 0.1 & 0.1 & - \\
\hline Lysine & 0.1 & 0.1 & 0.1 & 0.1 & 0.1 & 0.7 & 0.1 & - \\
\hline Ammonia & 0.2 & 0.1 & 0.2 & 0.2 & 0.2 & 0.3 & 0.2 & 0.2 \\
\hline Arginine & 7.4 & 6.4 & 5.5 & 1.1 & 1.17 & 6.67 & 1.05 & 2.3 \\
\hline Total amino acids & 18.2 & 13.5 & 13.0 & 13.8 & 13.37 & 27.76 & 10.25 & 7.6 \\
\hline
\end{tabular}

${ }^{2} \mathrm{M} 1$, control (1/2 MS); M2, without $\mathrm{NH}_{4}{ }_{4}^{+}$; M3, without $\mathrm{NO}_{3}$; $\mathrm{M} 4$, without $\mathrm{H}_{2} \mathrm{PO}_{4}{ }^{-}$; M5, without $\mathrm{K}^{+}$; M6, without $\mathrm{Ca}^{2+}$; M7, without $\mathrm{Mg}^{2+}$; and $\mathrm{M} 8$, without $\mathrm{Fe}^{3+}$.

${ }^{\mathrm{y}}$ No detection.

enormous effects on shoot and root growth of tea tree. The growth rate of a tea tree was high when it was cultured on medium without $\mathrm{Mg}^{2+}$, while the plantlets cultured on medium without $\mathrm{H}_{2} \mathrm{PO}_{4}{ }^{-}$showed poor shoot growth. This observation indicated that both $\mathrm{Mg}^{2+}$ and $\mathrm{H}_{2} \mathrm{PO}_{4}^{-}$are important factors governing tea plant growth. Magnesium $\left(\mathrm{Mg}^{2+}\right)$ is one of the essential mineral nutrients for the growth and development of plants. Magnesium also acts as activator or regulator of many key enzymes in plant physiological processes (Marschner, 1995). However, both $\mathrm{Mg}^{2+}$ deficiency and oversupply have detrimental effects on plant photosynthesis (Shabala and Hariadi, 2005), consequently resulting in abnormal or restricted growth (Shaul, 2002). In our study the correlation of magnesium requirement for the shoot and root growth of tea could not be reached as previously reported.

Phosphorus is one of the three main nutrients that plants require to thrive. It functions as one of the major players in the process of photosynthesis, nutrient transport, and energy transfer (Fageria et al., 1997). A plant with the proper amount of phosphorus available to it will grow more vigorously however, while its deficiency causes stunted growth, lack of fruit or flowers, wilting and leaves may be greener or have a purple cast to them due to the photosynthetic process being affected. This study also showed that indeed phosphorous is required for good growth of tea plant.

The plant morphology in general and leaf appearance in particular varied depending upon presence of mineral 
salt in growth medium. The tea plants cultured in medium without $\mathrm{H}_{2} \mathrm{PO}_{4}^{-}$showed less foliation. Chatuavedi (2006) reported that continuous supply of $\mathrm{H}_{2} \mathrm{PO}_{4}{ }^{-}$to the crop during crop-growth period, which is more beneficial and increased total number of tillers, dry matter accumulation and fertilizer-use efficiency and resulted in higher yields of the wheat. Mittal et al. (1978) had also reported similar findings. However, the relationship between leaf induction and $\mathrm{H}_{2} \mathrm{PO}_{4}^{-}$deficiency has not been reported so far.

The observation that higher browning of tea leaf in $\mathrm{Ca}^{2+}$ and $\mathrm{Fe}^{3+}$ free medium indicates that both of these minerals are key players in tea plant metabolism. Also, $\mathrm{H}_{2} \mathrm{PO}_{4}{ }^{-}$and $\mathrm{Ca}^{2+}$ deficiency resulted in necrosis of tea plant again substantiating the important roles of these minerals for tea tree cultivation.

Multiple shoot induction was high on $\mathrm{H}_{2} \mathrm{PO}_{4}, \mathrm{NH}_{4}{ }^{+}$and $\mathrm{NO}_{3}-$ free media. Varying strength of nutrient components of the basal media have been shown to markedly influence the micropropagation process in many plant species (Klimaszewska and Keller, 1985; Seetharam et al., 2007). Decreased $\mathrm{KNO}_{3}$ and iron were required to improve shoot multiplication (Poothong and Reed, 2014). Mohamed et al. (1987) reported that $\mathrm{FeSO}_{4}$ - $\mathrm{Fe}$ had a great effect on the total amino acids content and distribution of tomato. Iron increased the translocation of proline from roots to tomato leaves.

Mineral salts composition influence metabolite production of in vitro cultured tea trees. In both $\mathrm{Ca}^{2+}$ and $\mathrm{NH}_{4}{ }^{+}$free medium the catechin production was low, however, removal of $\mathrm{Fe}^{3+}$ from medium was beneficial in enhancement of the same. This fact indicated that these minerals; $\mathrm{Ca}^{2+}$, $\mathrm{NH}_{4}{ }^{+}$, and $\mathrm{Fe}^{3+}$ play critical role in catechin production in tea cultivations. Calcium can result in an enhancement of the secondary metabolite production (Sudha and Ravishankar, 2002). There is interplay of the signaling molecules also which regulates the entire pathway. Nitrogen on the soil $\mathrm{NO}_{3}-\mathrm{N}$ and $\mathrm{NH}_{4}-\mathrm{N}$ form is absorbed into plants is used in growth. The lack of nitrogen can weaken the growth of a plant and the growth of its roots (Mengel and Kirkby, 1987; Shear and Faust, 1980). Induction of secondary metabolite biosynthesis by lowering ammonium concentration was observed in ginseng saponin production by Panax quinquefolium (Zhong and Wang, 1998). Iron is also as important to health of plants. In plants, it acts as an oxygen carrier, helping form certain respirator enzyme systems in most crops. Hagendoorn et al. (1994) reported that addition of $\mathrm{Fe}^{3+}$ led to decreased lignin content and an increased cytoplasmic $\mathrm{pH}$. Fe ${ }^{2+}$ stress enhances ROS production via the Fenton reaction and promotes h-thujaplicin production via ROS induced lipid peroxidation that may activate cyclic oxylipin and ethylene pathways (Zhao et al., 2005).
Mineral salts can influence on amino acid biosynthesis of in vitro cultured tea trees. About 5.58 times higher total amino acid strength was observed following removal of $\mathrm{Ca}^{2+}$ from growth medium. However, in $\mathrm{Fe}^{3+}$ removed medium the amino acid content was lower than $\mathrm{Ca}^{2+}$ removed treatment. Thus, $\mathrm{Ca}^{2+}$ and $\mathrm{Fe}^{3+}$ may also play key roles during amino acid biosynthesis by cultured tea plants. Calcium promote production of this essential amino acid (Sheldon et al., 1951). The tryptophane in the forage was increasingly higher with increasing concentration of calcium. The presence of $\mathrm{Ca}^{2+}$ suggests a time-dependent change in cell membrane properties that may require the synthesis of a protein involved in transport. The $\mathrm{Ca}^{2+}$ may be involved in the binding of such protein to the membrane or maintaining a membrane conformation that favors protein binding to maintain an intact transport system (Harrington et al., 1981). Also, iron deficiencies were associated with large increases in the free levels of the two amides asparagine and glutamine from tomato (Possingham, 1957).

This study investigated the effects of mineral salts on plant growth, its physiology and secondary metabolites generation in tea tree. Response of plant cultures to in vitro and in vivo induced stress was similar (Sawwan et al., 2000). These experimental results once again establish the important roles played by various mineral salts. Such results and observations can be used as a basic data for the proper technical development for various soil controls and design of fertilizers suitable for tea tree cultivation area in the future.

\section{Literature Cited}

Albert, R. and H. Kinzel. 1973. Distinction between physiotypes of halophytic colonizers of sea-area (Eastreach). Plant Physiol. 70:138-157.

Bondarev, N.O., O. Reshetnyak, and A. Nosov. 2003. Effects of nutrient medium composition on development of Stevia rebaudiana shoots cultivated in the roller bioreactor and their production of steviol glycosides. Plant Sci. 165:845-850.

Chae, H.J., S.N. Yu, and D.G. Kim, 2006. Soil microflora and microfauna in 29 years of N-P-K fertilizer omission plot. Res. Plant Dis. 12:108-114.

Chatuavedi, I. 2006. Effects of phosphorus levels alone or in combination with phosphate-solubilizing bacteria and farmyard manure on growth, yield and nutrient up-take of wheat (Triticum aestivum). J. Agric. Social Sci. 2:96-100.

Eden, T. 1958. The development of tea culture, p. 1-4. In: T. Eden (ed.). Tea, Longman, London.

Fageria, N.K., V.C. Baligar, C.A. Jones. 1997. Common bean and cowpea, p. 441-490. In: N.K. Fageria, V.C. Baligar, and C.A. 
Jone (eds.). Growth and mineral nutrition of field crops. Marcel Dekker, New York.

Hagendoorn, M., A.M. Wagner, G. Segers, L. Van Der Plas, A. Oostdam, and H.S. Van Walraven. 1994. Cytoplasmic acidification and secondary metabolite production in different plant cell suspensions (a comparative study). Plant Physiol. 106:723-730.

Harrington, H.M., S.L. Berry, and R.R. Henke. 1981. Amino acid transport into cultured Tobacco cells: II. Effect of calcium. Plant Physiol. 67:379-384.

Kato, M., Y. Gyoten, K. Sakai-Kato, and T. Toyo'oka. 2003. Rapid analysis of amino acids in Japanese green tea by microchip electrophoresis using plastic microchip and fluorescence detection. J. Chromatogr. A 1013:183-189.

Klimaszewska, K. and W.A. Keller. 1985. High frequency plant regeneration from thin cell layer explants of Brassica napus. Plant Cell Tiss. Org. Cult. 4:183-197.

Kim, Y.D., J.Y. Min, M.J. Jeong, H.J. Song, J.G. Hwang, C.S. Karigar, G.W. Cheong, and M.S. Choi. 2010. Rapid selection of catechins-rich tea-trees (C. sinensis L.) by a colorimetric method. J. Wood Sci. 56:411-417.

Marschner, H. 1995. Mineral nutrition of higher plants. 2nd ed. Academic Press, London.

Mengel, K. and E.A. Kirkby. 1987. Principles of plant nutrition, p. 347-384. In: K. Mengel and E.A. Kirby (eds.). Interational Potash Institute, Bern, Switzerland.

Mittal, K.N., B.N. Lal, and C.K. Dwivedi. 1978. Effect of fertilizer on the productivity and quality of wheat. J. Agric. Res. 27:19-3.

Mohamed, A. A., I. H. El Sokkary, and T. C. Tucker. 1987. Growth and chlorophyll, mineral, and total amino acid composition of tomato and wheat plants in relation to nitrogen and iron nutrition II. Chlorophyll content and total amino acid composition. J. Plant Nutr. 10:713-731.

Murashige, T. and F. Skoog. 1962. A revised medium for rapid growth and bioassays with tobacco tissue culture. Physiol. Plant. 15:473-497.

Orians, C.M., S. Lower, R.S. Fritz, and B.M. Roche. 2003. The effects of plant genetic variation and soil nutrients on secondary chemistry and growth in a shrubby willow, Salix sericea: Patterns and constraints on the evolution of resistance traits. Biochem. Syst. Ecol. 31:233-247.

Park, T.G. and S.D. Song. 1995. Growth responses and regulations of nitrogen fixation activities of three leguminous plant treated with nitrogen and phosphorus. J. Environ. Sci. 9:127-136.

Poothong, S. and B.M. Reed. 2014. Modeling the effects of mineral nutrition for improving growth and development of micropropagated red raspberries. Sci. Hortic. 165:132-141.

Possingham, J.V. 1957. The effect of mineral nutrition on the content of free amino acids and amides in Tomato plants II. A study of the effect of molybdenum nutrition. Australian J. Biological Sci. 10:40-49.

Sawwan, J., R.A. Shibi, I. Swaidat, and M. Tahat. 2000. Phosphorus regulates osmotic potential and growth of African violet under in vitro induced water deficit. J. Plant. Nutr. 23:759-771.

Seetharam, Y.N., L.N. Rajanna, G. Jyothishwaran, B. Aravind, G. Sharanabasappa, and P.B. Mallikharjun. 2007. In vitro multiple shoot regeneration from nodal explants of Vernonia amygdalina-an important medicinal plant. Afr. Crop Sci. Conf. Proc. 8:747-752.

Shabala, S. and Y. Hariadi. 2005. Effects of magnesium availability on the activity of plasma membrane ion trans-porters and light-induced responses from broad bean leaf mesophyll. Planta 221:56-65.

Shear, C.B. and M. Faust. 1980. Nutritional ranges in deciduous tree fruits and nuts. Hort. Rev. 2:142-163.

Shaul, O. 2002. Magnesium transport and function in plants: The tip of the iceberg. Biometals 15:309-323.

Sheldon, V.L., W.M.G. Blue, and W.M.A. Albrecht. 1951. Biosynthesis of amino acids according to soil fertility. Plant Soil 3:361-365.

Shibli, R.A., M.M. Mohammad, A. Abu-Ein, and M. Shatnawi. 2000. Growth and micronutrient acquisition of some apple varieties in response to gradual in vitro induced salinity. J. Plant Nutr. 23:1209-1215.

Sudha, G. and G.A. Ravishankar. 2002. Involvement and interaction of various signaling compounds on the plant metabolic events during defense response, resistance to stress factors, formation of secondary metabolites and their molecular aspects. Plant Cell Tiss. Org. Cult. 71:181-212.

Zhao, J., K. Fujita, and K. Sakai. 2005. Oxidative stress in plant cell culture: A role in production of h-thujaplicin by Cupresssus lusitanica suspension culture. Biotechnol. Bioeng. 90:621-631.

Zhong, J.J. and S.J. Wang. 1998. Effects of nitrogen source on the production of ginseng saponin and polysaccharide by cell cultures of Panax quinquefolium. Process Biochem. 33:671-675. 